\title{
PEMBELAJARAN TEMATIK BERBASIS KONTEKSTUAL DI SD MUHAMMADIYAH 9 MALANG
}

\author{
Efi Nilasari ${ }^{1}$, Yudha Adrian ${ }^{2}$, Ratno Susanto ${ }^{3}$ \\ Diterima 8 November 2017, Dipublikasikan 17 April 2018 \\ CPenulis (2018)
}

\begin{abstract}
This study aims to: (1) describe contextual-based thematic learning plan that is implemented in Muhammadiyah Primary School 9 Malang, (2) to describe contextual contextual teachinglearning in elementary school Muhammadiyah 9 Malang; (3) to describe contextual based thematic learning evaluation in Muhammadiyah Primary School 9 Malang. Methods This study is a qualitative descriptive study that describes phenomena in the field without treatment. The object of this research is the students of grade V SD Muhammadiyah 9 Malang. Sources of data obtained from teachers and students of class $V$. In addition, learning tools used when the implementation of learning. Main techniques of data collection through observation, documentation and interviews as research support techniques. Data analysis techniques used are data reduction, data display and conclusion / verification. The results showed that contextual thematic learning planning at SD Muhammadiyah 9 Malang was good enough and run as it should be. Implementation of contextually thematic learning at SD Muhammadiyah 9 Malang still not in accordance with the planning. The practice of contextual approach to thematic learning is still less than optimal. This is because teachers are less well understood with the application of contextual based thematic approach. Finally, the implementation of thematic learning evaluation that is used is in accordance with the assessment standards used. Evaluation of learning that includes assessment of student learning outcomes that include aspects of attitude, knowledge and skills.
\end{abstract}

\section{Keywords}

Thematic Learning, Contextual Approach, Contextual Based Thematic Learning

\section{PENDAHULUAN}

Di setiap perjalanan hidup manusia akan selalu mengalami suatu proses perubahan ke arah yang baik dalam berbagai bentuk aspek secara fisik maupun non fisik. Perubahan tersebut akan terus menerus berlangsung seiring berkembangnya manusia. Melalui suatu proses pendidikan serta pembelajaran manusia dapat mengembangkan segala potensi yang ada dalam dirinya. Pendidikan merupakan suatu upaya pengembangan segala potensi peserta didik. Sebagaimana dimaksudkan dalam Undang - undang Nomor 20 Tahun 2003 tentang Sistem Pendidikan Nasional yang menyatakan bahwa pendidikan merupakan usaha sadar dan terencana untuk

\footnotetext{
SDN Lowokwaru 1 Malang cahayalintang90@yahoo.co.id

STKIP PGRI Banjarmasin

IKIP Budi Utomo Malang
}

Jurnal Teori dan Praksis Pembelajaran IPS Volume 3, No.1, 2018, 19-26 ISSN 2503-5307 
mewujudkan suasana belajar dan proses pembelajaran agar peserta didik secara aktif mengembangkan seluruh potensi dirinya untuk memiliki kekuatan spiritual keagamaan, pengendalian diri, kepribadian, kecerdasan, akhlak mulia, serta keterampilan yang diperlukan dirinya, masyarakat, bangsa dan negara. Pendidikan dapat dikatakan memiliki makna yang berhasil apabila dapat mencapai tujuan yang diharapkan dapat membentuk manusia yang berkembang dan memiliki potensi secara utuh melalui pengalaman nyata yang di dapatkannya. Melalui pengalaman nyata dapat memotivasi siswa dalam memahami makna materi pembelajaran yang dipelajarinya. Siswa usia sekolah dasar berada pada rentangan usia yang sangat dini. Pada usia dini seluruh aspek kecerdasan sedang terbentuk dan mulai tumbuh kembang. Proses pembelajaran yang siswa dapatkan bergantung dengan yang diterima melalui indera mereka mulai dari konkret hingga pengalaman yang dialami secara langsung. Oleh sebab itu kegiatan belajar di sekolah dasar perlu di rancang sesuai dengan kondisi tahap perkembangan siswa yang memandang segala sesuatunya secara utuh. Unsur utama pemikiran itulah perlu adanya pembelajaran yang dapat mengakomodasi keseluruhan kebutuhan siswa dalam belajar.

Melalui pembelajaran tematik yang merupakan pembelajaran yang sudah diterapkan sejak tahun 1994. Namun penekanan penggunaan pembelajaran tematik di terapkan pada tahun 2004 dan kemudian di jalankan kembali pada tahun 2013 hingga sekarang tahun 2017 tentu dengan banyaknya perubahan - perubahan yang signifikan. Melalui pembelajaran tematik ini siswa lebih bisa diarahkan secara terintegrasi mulai dari isi serta proses pembelajaran lintas kompetensi secara langsung dan menekankan pada keterlibatan siswa serta mengaitkan materi atau konsep - konsep belajar dengan situasi yang sesungguhnya di lingkungan belajar siswa dengan contextual teaching and learning.

Pembelajaran berbasis kontekstual merupakan konsep belajar yang ditunjukan oleh guru dengan menghadirkan dunia nyata ke dalam kelas dan mendorong siswa membuat hubungan antara pengetahuan yang dimiliki dengan penerapan dalam kehidupan sehari - hari (Siregar \& Nara:2014). Pembelajaran kontekstual dikatakan penting karena proses pembelajarannya menekankan kepada keterlibatan aktif siswa dalam belajar atau student centered and learning context. Proses belajarnya alamiah di mana siswa belajar mengalami tidak hanya menstransfer namun di latih untuk memecahkan masalah yang mereka hadapi dalam suatu situasi dan masalah yang memang ada dalam dunia nyata. Siswa tidak belajar dari proses seketika namun sedikit demi sedikit dan diukur melalui penilaian secara holistic yaitu autentik asesmen.

Berdasarkan hasil observasi yang dilakukan di SD Muhammadiyah 9 Malang, menunjukkan bahwa pembelajaran tematik yang sedang terjadi masih belum sesuai dengan perencanaan sedangkan untuk praktik pendekatan kontekstual pada pembelajaran tematik masih kurang maksimal untuk evaluasi sudah sesuai dengan standar penilaian yang digunakan.

Pembelajaran tematik adalah pembelajaran yang dirancang berdasarkan tema - tema tertentu yang menggunakan tema untuk mengaitkan beberapa muatan materi pelajaran sehingga memberikan pengalaman bermakna kepada siswa (Depdiknas, 2006:5). Selanjutnya Sukini (2012) menyatakan bahwa pembelajaran tematik merupakan salah satu model pembelajaran terpadu yang unsur utamanya menggunakan tema sebagai pengaitan beberapa mata pelajaran sehingga dapat memberikan pengalaman yang bermakna kepada siswa. Selaras dengan pendapat Trianto (2011:7) dan Towaf, dkk. (2017) pembelajaran tematik menawarkan suatu model yang unsur utamanya aktivitas pembelajaran yang relevan dan bermakna bagi siswa baik aktivitas normal maupun informal yang meliputi pembelajaran menemukan suatu konsep baru 
secara aktif sampai dengan penyerapan pengetahuan dan fakta secara pasif dengan memberdayakan pengetahuan serta pengalaman belajar siswa dalam memahami apa yang di pelajarinya dalam kehidupan.

Senada dengan pendapat Pratomo (2009) yang menjelaskan bahwasannya pembelajaran tematik merupakan suatu proses pembelajaran yang melibatkan beberapa bidang studi untuk memberikan suatu pengalaman yang bermakna kepada siswa. Bermakna yang dimaksudkan adalah pembelajaran yang memahami konsep yang sedang siswa pelajari melalui pengalaman yang mereka peroleh secara langsung dan mengaitkannya dengan konsep yang sudah siswa pahami sebelumnya. Berkaitan dengan pembelajaran tematik Fogarty (1991:14) mengemukakan bahwa pembelajaran tematik terdapat 10 model integrasi yaitu model fragmented, connected, nested, sequenced, shared, webbed, threaded, integrated, immersed, dan networked.

Contextual Teaching and Learning (CTL) merupakan suatu strategi pembelajaran yang menekankan kepada proses keterlibatan siswa secara penuh untuk dapat menemukan materi yang dipelajari dan menghubungkannya dengan situasi kehidupan nyata sehingga mendorong siswa untuk dapat menerapkannya dalam kehidupan mereka Sanjaya (2006). Pernyataan selaras juga di kemukakan oleh Hasnawati (2006) pendekatan kontekstual merupakan suatu konsep pembelajaran yang dalam penerapannya menekankan pada keterlibatan siswa dalam mengkonstruksi sendiri pengelamannya, melatih berpikir secara kritis melalui kegiatan menemukan masalahnya sendiri, memberikan keleluasaan bertanya serta melatih siswa untuk belajar bekerjasama saling berbagi dan menerapkannya pada lingkungan sehari - hari serta dapat memudahkan guru untuk memberdayakan potensi siswa sesuai dengan kebutuhan serta lingkungan sekolah dan kehidupannya. Pembelajaran kontekstual cenderung menitikberatkan pada hubungan antara materi yang dipelajari siswa dengan kegunaan praktis dalam kehidupan sehari - hari. Diknas (2002) mengemukakan bahwa pembelajaran kontekstual melibatkan tujuh komponen utama yakni: 1) Kontruksivisme, 2) Bertanya, 3) Menemukan, 4) Masyarakat belajar, 5) Pemodelan, 6) Refleksi dan Penilaian sebenarnya.

Ketujuh konsep utama model tersebut dapat dijelaskan sebagai berikut. (1) Konstruktivisme merupakan landasan berpikir pendekatan kontekstual yakni pengetahuan yang dibangun oleh siswa dengan sedikit demi sedikit, yang hasilnya diperluas melalui konteks terbatas. Pengetahuan dikonstruksi melalui pengalaman nyata. (2) Bertanya, bertanya merupakan unsur utama dalam pembelajaran yang kontekstual dan dipandang sebai faktor pendorong dan juga merupakan bagian dari pembelajaran yang berbasis inkuiri yang menggali informasi, mengkonfirmasi apa yang sudah diketahui dan mengarahkan pada aspek yang sudah diketahui dan aspek yang belum diketahui. (3) Menemukan (inkuiri) merupakan kegiatan ini dalam pembelajaran kontekstual. Pengetahuan yang didapat serta keterampilan siswa diharapkan bukan hasil mengingat semua fakta - fakta tetapi hasil dari menemukan sendiri. (4) Masyarakat belajar, konsep masyarakat belajar didapatkan dari hasil kerja sama dengan orang lain. Di dalam kelas pembelajaran kontekstual guru diharapkan melaksanakan pembelajaran dalam kelompok - kelompok belajar. Dalam contoh ini yang belajar siswa bukan guru dan di dalamnya terlibat dua kelompok atau lebih komunikasi pembelajaran saling belajar. (5) Pemodelan, maksudnya di dalam pembelajaran pengetahuan serta ketrampilan tertentu terdapat ada model yang bisa di tiru seperti guru memberi contoh cara mengerjakan sesuatu. (6) Refleksi, merupakan bagian yang penting dalam pembelajaran dengan pendekatan kontekstual. Refleksi merupakan cara berpikir tentang apa yang baru dipelajari dan berpikir ke arah belakang serta apa- apa yang 
sudah dilakukan. Pengetahuan yang bermakna diperoleh dari sebuah proses pengetahuan yang telah dimiliki siswa yang kemudian diperluas melalui konteks pembelajaran, yang kemudian diperluas sedikit - demi sedikit. Dengan seperti itu siswa merasa memperoleh sesuatu yang bermakna bagi dirinya tentang apa yang telah dipelajarinya. dan (7) Penilaian sebenarnya, asesmen merupakan proses pengumpulan data yang bisa memberikan gambaran perkembangan belajar siswa. Gambaran perkembangan belajar siswa perlu diketahui oleh guru agar bisa memastikan bahwa siswa mengalami proses pembelajaran dengan benar.

Berdasarkan dari definisi tersebut dapat disimpulkan bahwa CTL merupakan proses pembelajaran yang unsur utamanya menekankan kepada proses terlibatnya siswa secara aktif dalam memahami muatan materi pelajaran melalui pengalaman siswa dalam belajar secara langsung dan mengaitkan materi yang diterimanya dengan situasi yang sebenarnya.

\section{PERENCANAAN PEMBELAJARAN}

Penerapan pembelajaran tematik berbasis kontekstual di SD Muhammadiyah 9 Malang meliputi tiga tahapan penting. Tahapan pertama adalah tahapan perencanaan pembelajaran yang meliputi pengembangan silabus, RPP, bahan ajar, media pembelajaran, dan alat evaluasi hasil pembelajaran siswa. Pada tahapan ini pertama guru mengembangkan silabus. Pengembangan silabus terkait penyusunan KD (kompetensi dasar), indikator pembelajaran, materi pembelajaran, alokasi waktu, dan sumber belajar. Pengembangan silabus mengacu pada kebutuhan siswa terhadap materi yang akan dibelajarkan. Dengan kata lain, guru harus memperhatikan kemampuan awal siswa. dengan mengetahui kemampuan awal siswa, maka guru dapat menentukan indikator-indikator pembelajaran sehingga kemampuan siswa dapat benar-benar terukur dan terarah. Secara rinci pengembangan KD dan indikator pembelajaran dijabarkan pada tabel 1 .

Tabel 1 Jaringan KD dan Indikator (Pembelajaran 1)

\begin{tabular}{|c|c|c|}
\hline No & Kompetensi Dasar & Indikator \\
\hline 1 & $\begin{array}{l}\text { Bahasa Indonesia } \\
\text { 3.1 Menggali informasi dari teks laporan buku } \\
\text { tentang makanan dan rantai makanan, kesehatan } \\
\text { manusia, keseimbangan ekosistem, serta alam } \\
\text { dan pengaruh kegiatan manusia dengan bantuan } \\
\text { guru dan teman dalam bahasa Indonesia lisan } \\
\text { dan tulis dengan memilih dan memilah kosakata } \\
\text { baku } \\
\text { 4.1 Mengamati, mengolah, dan menyajikan teks } \\
\text { laporan buku tentang makanan dan rantai } \\
\text { makanan, kesehatan manusia, keseimbangan } \\
\text { ekosistem, serta alam dan pengaruh kegiatan } \\
\text { manusia secara mandiri dalam bahasa Indonesia } \\
\text { lisan dan tulis dengan memilih dan memilah } \\
\text { kosakata baku }\end{array}$ & $\begin{array}{l}\text { 1. Menemukan kata sulit dalam teks bacaan } \\
\text { 2. Menyajikan informasi yang berkaitan dengan } \\
\text { teks bacaan tentang lingkungan dalam bentuk } \\
\text { peta pikiran } \\
\text { 3. Menuliskan tiga contoh kegiatan yang dapat } \\
\text { menjaga lingkungan sekitar. } \\
\text { 4. Menyusun minimal } 5 \text { pertanyaan yang sesuai } \\
\text { dengan topik lingkungan } \\
\text { 5. Menentukan minimal tiga sumber wawancara } \\
\text { yang sesuai topik lingkungan. } \\
\text { 6. Menuliskan laporan hasil wawancara }\end{array}$ \\
\hline 2 & $\begin{array}{l}\text { Matematika } \\
\text { dari sekumpulan data }\end{array}$ & $\begin{array}{l}\text { 1. Menjelaskan pengertian dari (mean) } \\
\text { sekumpulan data } \\
\text { 2. Mengurutkan data dari yang terkecil hingga ke } \\
\text { terbesar. }\end{array}$ \\
\hline 3 & $\begin{array}{l}\text { IPA } \\
\text { 3.3 Mengidentifikasi perubahan yang terjadi di } \\
\text { alam, hubungannya dengan penggunaan sumber } \\
\text { daya alam, dan pengaruh kegiatan manusia } \\
\text { terhadap keseimbangan lingkungan sekitar }\end{array}$ & $\begin{array}{l}\text { 1. Mengidentifikasi minimal contoh kegiatan } \\
\text { manusia yang menguntungkan lingkungan. } \\
\text { 2. Mengidentifikasi minimal contoh kegiatan } \\
\text { manusia yang merugikan lingkungan } \\
\text { 3. Mengamati perubahan ketidakseimbangan } \\
\text { yang terjadi di lingkungan sekolah. }\end{array}$ \\
\hline
\end{tabular}




No Kompetensi Dasar Indikator

4. Mengamati perubahan ketidakseimbangan yang terjadi di lingkungan rumah

Berdasarkan tabel di atas dijelaskan bahwa tiga muatan yang dikembangkan dalam proses perencanaan pembelajaran. Muatan tersebut adalah muatan Bahasa Indonesia, Matematika, dan IPA. Muatan pembelajaran ini dinaungi oleh pendekatan tematik terpadu sesuai dengan kurikulum 2013. Setelah penyusunan indikator pembelajaran telah disusun. Selanjutnya, guru menyusun tujuan pembelajaran dari berbagai muatan tersebut. hal ini dilakukan untuk mempermudah guru dalam merancang kegiatan pembelajaran di kelas. secara rinci tujuan pembelajaran disusun pada tabel 2.

Tabel 2 Perumusan Tujuan Pembelajaran (Pembelajaran 1)

No Indikator Tujuan Pembelajaran

\section{Bahasa Indonesia}

1. Menemukan kata sulit dalam teks bacaan

2. Menyajikan informasi yang berkaitan dengan teks bacaan tentang lingkungan dalam bentuk peta pikiran

3. Menuliskan tiga contoh kegiatan yang dapat menjaga lingkungan sekitar.

4. Menyusun minimal 5 pertanyaan yang sesuai dengan topik lingkungan

5. Menentukan minimal tiga sumber wawancara yang sesuai topik lingkungan.

6. Menuliskan laporan hasil wawancara

\section{$2 \quad$ Matematika}

1. Menjelaskan pengertian dari (Mean) sekumpulan data

2. Mengurutkan data dari yang terkecil hingga ke terbesar.

\section{IPA}

1. Mengidentifikasi minimal contoh kegiatan manusia yang menguntungkan lingkungan.

2. Mengidentifikasi minimal contoh kegiatan manusia yang merugikan lingkungan

3. Mengamati perubahan ketidakseimbangan yang terjadi di lingkungan sekolah.

4. Mengamati perubahan ketidakseimbangan yang terjadi di lingkungan rumah
1. Melalui penugasan siswa dapat menyajikan informasi yang berkaitan dengan teks bacaan tentang lingkungan dalam bentuk peta pikiran dengan benar

2. Melalui penugasan siswa dapat menuliskan contoh kegiatan yang dapat menjaga lingkungan sekitar.

3. Melalui penugasan siswa dapat mengidentifikasi kata - kata sulit dalam bacaan teks dalam sebuah artikel berita dengan benar

4. Melalui penugasan siswa dapat menyusun minimal lima pertanyaan yang sesuai dengan topik lingkungan

5. Melalui penugasan siswa dapat menentukan minimal lima tiga sumber wawancara yang sesuai dengan topik kondisi lingkungan.

6. Melalui diskusi kelompok siswa dapat menuliskan laporan hasil wawancara

7. Melalui penugasan siswa dapat menyelesaikan soal yang berkaitan dengan sekumpulan data dengan benar

8. Melalui penugasan siswa dapat mengurutkan data mulai dari yang terkecil hingga yang terbesar dengan benar.

9. Melalui penugasan siswa dapat mengumpulkan data dan menyajikannya dalam bentuk tabel dengan benar.

10. Melalui pengamatan gambar kegiatan manusia yang mempengaruhi keseimbangan lingkungan, siswa dapat mengidentifikasi contoh gambar kegiatan manusia yang menguntungkan dan merugikan dengan benar.

11. Melalui penugasan dengan mengamati gambar tentang lingkungan sekitar siswa dapat mengindentifikasi contoh kegiatan manusia yang merugikan lingkungan sekitar dengan benar.

12. Melalui kegiatan diskusi siswa dapat mengamati perubahan ketidakseimbangan yang terjadi di lingkungan sekolahnya.

13. Melalui kegiatan diskusi siswa dapat mengamati perubahan ketidakseimbangan yang terjadi di lingkungan rumah. 
RPP disusun berdasarkan silabus yang telah dikembangkan oleh guru. RPP secara umum tersusun atas $\mathrm{KD}$, tujuan pembelajaran, materi pembelajaran, metode pembelajaran, langkahlangkah pembelajaran, sumber belajar, dan penilaian. Seperti yang dirumuskan pada silabus, tujuan pembelajaran, materi pembelajaran, metode pembelajaran, langkah-langkah pembelajaran, sumber belajar, dan penilaian yang dikembangkan di dalam RPP pada dasarnya dipilih untuk menciptakan proses pembelajaran untuk mencapai SK dan KD. Oleh karena itu, agar RPP memberi petunjuk pada dosen dalam menciptakan pembelajaran yang berwawasan berbasis kontekstual. RPP ini dirancang akan mempermudah guru menuliskan langkah-langkah pembelajaran yang mengacu pada pendekatan kontekstual.

Bahan ajar merupakan komponen pembelajaran yang tidak kalah penting pada proses pembelajaran. Penyusunan bahan ajar mengacu pada KD dan tujuan pembelajaran yang telah disusun pada silabus dan RPP. Bahan ajar ini memuat materi-materi yang mencerminkan pendekatan kontekstual. Materi-materi yang dimuat pada bahan ajar tidak lepas dari kehidupan siswa. materi-materi yang disusun disesuaikan dengan lingkungan tempat tinggal siswa. dengan kata lain, guru menyisipkan materi-materi terkait dengan kondisi-kondisi di kota Malang. Sebagai contoh: guru memuat materi tentang sumber daya alam di kota Malang.

Alat ukur yang disusun oleh guru merupakan tes hasil belajar kognitif siswa. tes ini disusun disesuaikan dengan indikator yang ditetapkan pada silabus dan RPP. alat ukur ini digunakan untuk mengukur kemampuan siswa. setelah kemampuan siswa dapat diukur, maka hasilnya dapat dinilai. Melalui kegiatan penilaian, guru dapat mengetahui progres dan kemampuan akhir siswa. selain itu, guru dapat melakukan refleksi pembelajaran yang dilakukan.

\section{PELAKSANAAN PEMBELAJARAN}

Pada tahap pelaksanaan pembelajaran, guru tidak sepenuhnya melaksanakan pembelajaran mengacu pada RPP yang telah disusun sebelumnya. padahal, di RPP telah jelas setiap langkah yang harus dilakukan agar tidak lepas dari perencanaan awal. Guru masih kebingungan dalam menentukan praktik dalam proses pembelajaran. Guru belum mampu melaksanakan semua langkah-langkah yang dibuat di RPP. Hal ini disebabkan, guru menganggap pendekatan kontekstual merupakan hal baru bagi guru, sehingga guru menjadi canggung dalam melaksanakannya di dalam kelas.

Meskipun guru masih kebingungan dalam melaksanakan langkah-langkah pembelajaran kontekstual, guru masih terbantu dengan adanya bahan ajar yang mengacu pada RPP berbasis kontekstual. Pada bahan ajar tersebut memuat konten-konten materi berbasis kontekstual. Pada bahan ajar berbentuk guru memuat tujuan pembelajaran, materi, gambar, dan evaluasi pembelajaran. Tujuan pembelajaran tersebut mengacu pada RPP yang telah disusun. Materi yang dimuat pada bahan ajar tersebut mendeskripsikan tentang kondisi atau kehidupan di lingkungan tempat tinggal siswa khususnya lingkungan kota Malang. Materi yang disusun disesuaikan dengan kondisi sebenarnya memungkinkan siswa untuk lebih mudah dalam menyerap pelajaran yang diajarkan oleh guru.

Bahan ajar yang dibuat berbasis pendekatan kontekstual sangat membantu guru dalam melaksanakan pembelajaran di ruang kelas. Pada pelaksanaan pembelajaran, guru menjadi fasilitator yang memfasilitasi siswa dalam menemukan pengetahuannya sendiri. Kekurangan guru dalam memahami pembelajaran tematik berbasis kontekstual dapat tertutupi dengan adanya bahan ajar berbasis kontekstual. 


\section{EVALUASI}

Pada tahap evaluasi merupakan tahap terpenting bagi guru dan siswa. Pada tahap ini kemampuan siswa dapat diukur melalui alat ukur yang telah disusun sedemikian rupa disesuaikan dengan KD dan indikator yang disusun pada RPP. Jenis alat ukur yang digunakan dalam proses pembelajaran di kelas menggunakan alat ukur tes berbentuk pilihan ganda. Pemilihan instrumen ini digunakan untuk mengukur pengetahuan siswa terkait materi yang dibelajarkan di dalam kelas.

Sebelum instrumen disusun, guru menyusun kisi-kisi soal. Tujuan penyusunan kisi-kisi soal agar mempermudah guru dalam membuat soal. Selain itu, agar mempermudah guru membuat pilihan atau opsi pada pilihan jawaban. Ringkasnya pembuatan kisi-kisi mempermudah guru menyusun soal agar tidak keluar dari indikator pencapaian yang diharapkan oleh guru. Hal tidak kalah penting, guru akan lebih mudah menentukan level taksonomi yang dibuat pada soal tersebut.

Penggunaan alat ukur tes pilihan ganda dianggap lebih mudah untuk menilai kemampuan siswa. Guru hanya menghitung jumlah jawaban benar siswa dan menjumlahkannya. Dengan demikian, kemampuan siswa dalam memahami pelajaran dapat dengan mudah diukur tanpa memerlukan waktu yang lama.

Penggunaan tes pilihan ganda dilakukan di akhir proses pelaksanaan pembelajaran di kelas. Hal ini bertujuan untuk mengukur kemampuan akhir siswa. Setelah kemampuan siswa telah terukur, maka guru memberikan penilaian pada hasil belajar siswa. Dengan demikian, hasil belajar yang telah terukur dapat dijadikan patokan keberhasilan proses pembelajaran yang telah dilaksanakan di dalam kelas.

\section{SIMPULAN}

Pembelajaran tematik berbasis kontekstual yang dilaksanakan di sekolah dasar Muhammadiyah 9 Malang awal mulanya masih belum sesuai dengan perencanaan sedangkan dalam pembelajaran di rasa kurang maksimal karena guru masih kurang begitu paham dengan penerapan pembelajaran yang menggunakan pendekatan kontekstual. Sedangkan untuk pelaksanaan evaluasi sudah sesuai standar yang ditentukan yang mencakup ranah aspek sikap, pengetahuan dan ketrampilan.

Studi pendahuluan penting dilaksanakan terlebih dahulu sebelum pembelajaran berbasis kontekstual dilaksanakan. Karena pengembang terlebih dahulu menganalisis kebutuhan agar pembelajaran yang dikembangkan sesuai serta tepat sasaran. Berdasarkan hasil telaah diharapkan guru lebih bisa memahami pembelajaran kontekstual dan dapat di laksanakan dalam pembelajaran di sekolah.

\section{DAFTAR PUSTAKA}

Depdiknas. 2006. Model Pembelajaran Tematik Kelas Awal Sekolah Dasar.Jakarta: Puskur Balitbang Depdiknas.

DIKNAS (2002).Pendekatan Kontekstual (Contextual Teaching and Learning) Jakarta: Diknas.

Fogarty, Robin. 1991. The Meaningful School : How to integrate the Curricula.IIIinois.Skylight Publishing, Inc.

Hasnawati.2006.Pendekatan Contextual Teaching Learning Hubungan dengan Evaluasi Pembelajaran. Jurnal Ekonomi \& Pendidikan; Vol 3 (1) 
Moleong, Lexy.2010.Metodologi Penelitian Kualitatif. Bandung: Remaja Rosdakarya.

Pratomo,Suko.2009.Model Pembelajaran Tematik dalam Pendidikan Lingkungan Hidup (PLH) di Sekolah Dasar. Jurnal Pendidikan Dasar, Nomor 11 April 2009:8-15.

Siregar, Eveline \& Nara Hartini. Teori Belajar dan Pembelajaran.2014.Bogor:Ghalia Indonesia

Sukini.2012.Pembelajaran Tematik di sekolah dasar kelas rendah dan pelaksanaanya, Jurnal Magistra No 82 Th. XXIV. ISSN di akses 16 September 2014.

Sugiyono.2010. Metode Penelitian Pendidikan Pendekatan Kuantitaif, Kualitatif, dan RnD. Bandung: Alfabeta.

Sugiyono.2013. Metode Penelitian Pendidikan Pendekatan Kuantitaif, Kualitatif, dan RnD. Bandung: Alfabeta.

Sanjaya, Wina.2006. Strategi Pembelajaran Berorientasi Standar Proses Pendidikan. Jakarta: Kencana.

Towaf, Siti Malikhah, dkk. 2017. IPS Tematik Terpadu Berbasis Lapangan: Buku Guru. Malang: Program Studi Pendidikan IPS

Trianto.2011. Model Pembelajaran Terpadu. Jakarta: Bumi Aksara. 